\title{
Antibiotic resistance of motile aeromonads in indoor catfish and eel farms in the southern part of The Netherlands
}

Citation for published version (APA):

Penders, J., \& Stobberingh, E. E. (2008). Antibiotic resistance of motile aeromonads in indoor catfish and eel farms in the southern part of The Netherlands. International Journal of Antimicrobial Agents, 31(3), 261-5. https://doi.org/10.1016/j.ijantimicag.2007.10.002

Document status and date:

Published: 01/01/2008

DOI:

10.1016/j.jjantimicag.2007.10.002

Document Version:

Publisher's PDF, also known as Version of record

Document license:

Taverne

Please check the document version of this publication:

- A submitted manuscript is the version of the article upon submission and before peer-review. There can be important differences between the submitted version and the official published version of record.

People interested in the research are advised to contact the author for the final version of the publication, or visit the DOI to the publisher's website.

- The final author version and the galley proof are versions of the publication after peer review.

- The final published version features the final layout of the paper including the volume, issue and page numbers.

Link to publication

\footnotetext{
General rights rights.

- You may freely distribute the URL identifying the publication in the public portal. please follow below link for the End User Agreement:

www.umlib.nl/taverne-license

Take down policy

If you believe that this document breaches copyright please contact us at:

repository@maastrichtuniversity.nl

providing details and we will investigate your claim.
}

Copyright and moral rights for the publications made accessible in the public portal are retained by the authors and/or other copyright owners and it is a condition of accessing publications that users recognise and abide by the legal requirements associated with these

- Users may download and print one copy of any publication from the public portal for the purpose of private study or research.

- You may not further distribute the material or use it for any profit-making activity or commercial gain

If the publication is distributed under the terms of Article $25 \mathrm{fa}$ of the Dutch Copyright Act, indicated by the "Taverne" license above, 


\title{
Short communication Antibiotic resistance of motile aeromonads in indoor catfish
and eel farms in the southern part of The Netherlands
}

\author{
J. Penders ${ }^{\mathrm{a}, \mathrm{b}, *}$, E.E. Stobberingh ${ }^{\mathrm{b}}$ \\ a Nutrition and Toxicology Research Institute Maastricht, Department of Epidemiology, Maastricht University, \\ P.O. Box 616, 6200 MD Maastricht, The Netherlands \\ ${ }^{\mathrm{b}}$ Department of Medical Microbiology, University Hospital of Maastricht, P.O. Box 5800, \\ 6202 AZ Maastricht, The Netherlands
}

Received 1 August 2007; accepted 4 October 2007

\begin{abstract}
The prevalence and degree of antibiotic resistance in catfish and eel farms in the southern part of The Netherlands was examined using motile aeromonads as indicator bacteria. A total of 29 water samples were collected, originating from six catfish farms, one catfish hatchery and three eel farms, and were plated on an Aeromonas-selective agar with and without antibiotics. From each plate, one colony was screened for presumptive motile aeromonads and tested for antibiotic susceptibility. The prevalence of resistance was as follows: ampicillin and oxytetracycline $100 \%$; sulfamethoxazole $24 \%$; trimethoprim $3 \%$; and ciprofloxacin and chloramphenicol $0 \%$. The majority of samples showed a high degree of oxytetracycline resistance, implicating fish farms as a major reservoir of oxytetracycline resistance genes. This reservoir might form a risk for human health and has major consequences for the effectiveness of this antibiotic in the treatment of infectious diseases in fish.
\end{abstract}

(C) 2007 Elsevier B.V. and the International Society of Chemotherapy. All rights reserved.

Keywords: Aeromonas hydrophila; Antimicrobial resistance; Fish farms; Oxytetracycline

\section{Introduction}

Aquaculture nowadays belongs to one of the fastest growing food production systems in the world. Since world fish stocks are reaching the limits of exploitation, we have to rely to a far greater extent on products from aquaculture. Although most aquaculture production is present in Asia, fish farming is also increasing in Europe. The Netherlands is one of the main producers of eel and catfish in Europe. The unfavourable climate in Western Europe led to the development of indoor recirculation systems.

There is a serious risk of colonisation, spread and infection with (antibiotic-resistant) bacteria when animals are living in high densities. Therefore, antibiotics are administered prophylactically as well as therapeutically to food animals. Potential consequences of antibiotic use in animal feeds are the development of drug-resistant bacteria, multiple antibi-

\footnotetext{
* Corresponding author. Tel.: +31 43388 2385; fax: +31 433884128 .

E-mail address: j.penders@epid.unimaas.nl (J. Penders).
}

otic resistance, resistance transfer to pathogenic bacteria and reduced efficacy of antibiotic treatment for human and animal diseases caused by resistant pathogens [1].

Indeed, in a number of studies mass medication with antibiotics has been shown to select for the presence of large numbers of resistant Escherichia coli in the intestinal flora of animals [2]. Only a few studies have described the effects of antibiotics on the bacterial microflora of fish and fish-rearing waters [3-6]. The objectives of this study were to determine the prevalence and degree of antibiotic resistance in eel and catfish farms in the southern part of The Netherlands using motile aeromonads as indicator bacteria.

\section{Materials and methods}

\subsection{Sample collection}

Water samples were collected from all of the catfish farms in the southern part of The Netherlands $(n=6)$, one catfish 
hatchery and three eel farms. There are approximately 20 catfish farms throughout The Netherlands, supplying $90 \%$ of the European catfish market.

The Dutch catfish farms culture African catfish (Clarias gariepinus) in so-called recirculation systems. These systems are situated indoors and consist of fish tanks of ca. $100 \mathrm{~m}^{3}$ per tank, a sedimentation unit, a pump and a biological filter. The optimal growth temperature for African catfish is between $24^{\circ} \mathrm{C}$ and $26^{\circ} \mathrm{C}$, therefore the water temperature needs to be regulated by a heating system. The fish are kept in high densities up to $400 \mathrm{~kg} / \mathrm{m}^{3}$. The Dutch eel (Anguilla anguilla) farms culture their fish in similar recirculation systems, the main differences being the oxygen regulation and lower densities $\left(100 \mathrm{~kg} / \mathrm{m}^{3}\right)$. Each fish farm consists of at least two recirculation systems.

At each farm, two to four water samples were collected derived from different recirculation systems. The water samples were collected aseptically in sterile bottles and immediately placed on ice and transported to the microbiological laboratory of the Department of Medical Microbiology of Maastricht University.

\subsection{Microbiological analysis of water samples}

In the laboratory, $20 \%$ glycerol was added to the water samples, after which the samples were stored at $-20^{\circ} \mathrm{C}$ and assayed within $24 \mathrm{~h}$. One hundred microlitres of the water samples were then inoculated using a spiral plater (Spiral Systems Inc. Salm en Kip, Utrecht, The Netherlands) on Aeromonas Medium Base (Ryan) agar (Oxoid CM833; Oxoid Ltd., Basingstoke, UK).

To determine the prevalence of resistance, antibiotics were used in the agar at the following concentrations: ampicillin $(25 \mathrm{mg} / \mathrm{L})$; ciprofloxacin $(4 \mathrm{mg} / \mathrm{L})$; oxytetracycline $(25 \mathrm{mg} / \mathrm{L})$; chloramphenicol $(25 \mathrm{mg} / \mathrm{L})$; trimethoprim $(8 \mathrm{mg} / \mathrm{L})$; and sulfamethoxazole $(100 \mathrm{mg} / \mathrm{L})$. After $18-24 \mathrm{~h}$ of incubation at $30^{\circ} \mathrm{C}$, the agar plates were incubated for another $18-24 \mathrm{~h}$ at room temperature.

Aeromonas spp. grow on this agar with dark green, opaque colonies with a darker centre. Only these colonies were counted. From each plate without antibiotics, three colonies that answered the description of Aeromonas were picked up and screened for presumptive motile aeromonad isolates with a panel of tests including Gram reaction, motility, catalase and oxidase production, fermentative utilisation of glucose and susceptibility to 2,4-diamino-6,7-di-isopropyl pteridine phosphate $(\mathrm{O} / 129)$.

For phenotypic identification of the isolates, the following biochemical tests were performed: esculin hydrolysis; lysine and ornithine decarboxylase; acid from sucrose and L-arabinose; Voges-Proskauer; and indole. These tests are based upon a modification of the Aerokey II [7], a flexible identification systems that has been shown to be valid in identifying the seven most common motile Aeromonas spp. (Aeromonas caviae, Aeromonas hydrophila, Aeromonas veronii biovar veronii, A. veronii biovar sobria,
Aeromonas trota, Aeromonas schubertii and Aeromonas jandaei).

\subsection{Prevalence of antibiotic resistance}

The prevalence of antibiotic resistance (\%) was defined as the number of samples that grew on antibiotic-containing plates divided by the total number of samples tested $\times 100 \%$.

\subsection{Degree of antibiotic resistance}

The degree of antibiotic resistance of each water sample to each of the antibiotics tested was assessed as the number of colony-forming units (CFU) of resistant Aeromonas spp. divided by the total number Aeromonas spp. $\times 100 \%$. Two degrees of antibiotic resistance were distinguished: low degree of resistance, i.e. when $<50 \%$ of the aeromonad isolates from a fish farm were resistant; and high degree resistance, when $\geq 50 \%$ (thus the majority) were resistant to that particular agent.

\subsection{Antibiotic susceptibility testing}

Antibiotic susceptibility testing of the motile aeromonad strains isolated from the Ryan agar plates was determined using a microbroth dilution method in Iso-Sensitest broth (Oxoid CM473; Oxoid Ltd.) with an inoculum of $5 \times 10^{5} \mathrm{CFU} /$ well. The antimicrobial agents tested and the breakpoint concentrations for susceptibility according to the guidelines of the National Committee for Clinical Laboratory Standards were as follows: ampicillin $(32 \mathrm{mg} / \mathrm{L})$; chloramphenicol (32 mg/L); oxytetracycline $(16 \mathrm{mg} / \mathrm{L})$; ciprofloxacin $(4 \mathrm{mg} / \mathrm{L})$; and trimethoprim $(4 \mathrm{mg} / \mathrm{L})$.

After incubation for $18-24 \mathrm{~h}$ at $37^{\circ} \mathrm{C}$, the minimal inhibitory concentration (MIC) was determined as the lowest concentration that inhibited visible growth. The following reference strains were included as standards in all tests: $E$. coli ATCC 35218 and Enterococcus faecalis ATCC 29212.

\section{Results}

A total of 29 water samples were collected originating from 10 fish farms. Ninety-one percent (79/87) of the strains isolated for identification were motile Aeromonas. These 79 strains were further identified to species level: $31(39 \%)$ were A. caviae, $5(6 \%)$ were A. veronii biovar sobria and $43(54 \%)$ were A. hydrophila. The total number of motile aeromonads isolated from the different samples ranged between $1 \times 10^{5}$ and $1 \times 10^{7} \mathrm{CFU} / \mathrm{mL}$ of water.

\subsection{Prevalence of antibiotic resistance}

The prevalence of resistance to ampicillin and oxytetracycline was $100 \%$ and to sulfamethoxazole it was $24 \%$. Resistance to trimethoprim was found in only one sample. 


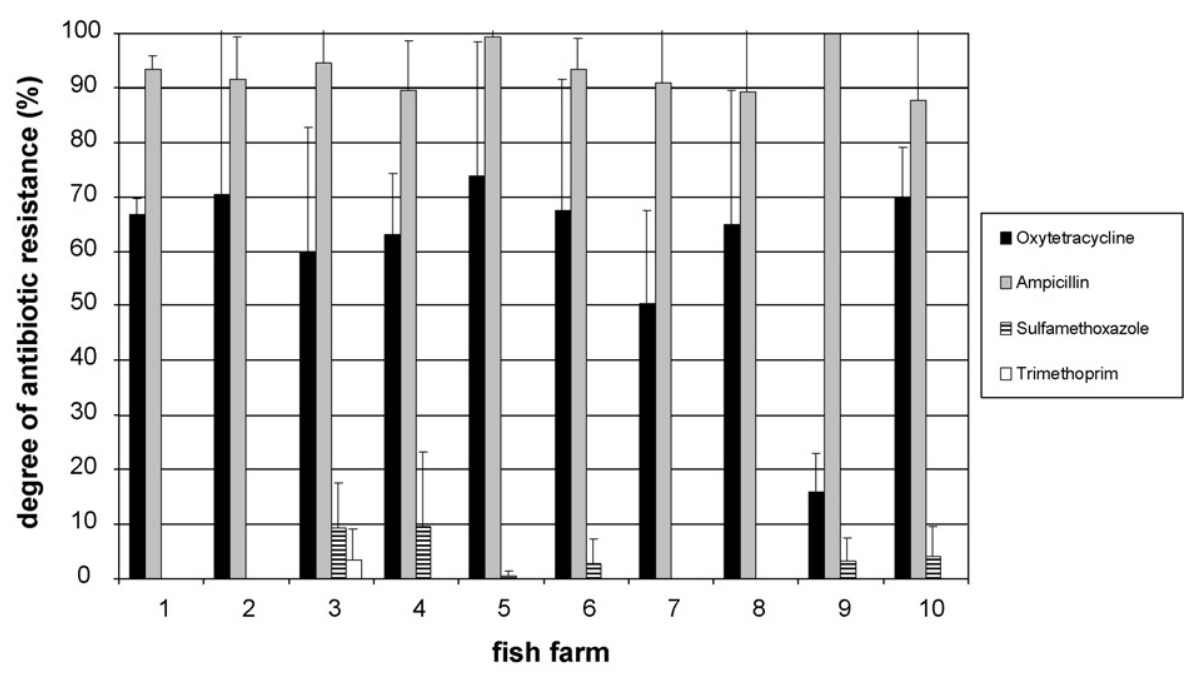

Fig. 1. Degree of antibiotic resistance to the antibiotics under study per fish farm. 1, 3, 4, 5, 6 and 7, catfish farms; 2, catfish hatchery; 8, 9 and 10, eel farms.

Resistance to ciprofloxacin and chloramphenicol was absent in the samples tested.

\subsection{Degree of antibiotic resistance}

The degree of resistance to the antibiotics tested is given in Fig. 1. As expected, the highest degree of resistance was observed for ampicillin. With the exception of fish farm 9, all fish farms showed a high degree of resistance $(>50 \%$ of the aeromonads isolates) to oxytetracycline. None of the samples showed a high degree of resistance to chloramphenicol, ciprofloxacin, trimethoprim or sulfamethoxazole. No differences could be observed between catfish and eel farms regarding the degree of resistance to the antibiotics under study.

\subsection{Antibiotic susceptibility}

Antibiotic susceptibility was determined for the 79 strains. Resistance to oxytetracycline, ampicillin and trimethoprim was found in $51(65 \%), 76(96 \%)$ and $18(23 \%)$ strains, respectively. No resistance to ciprofloxacin or chloramphenicol was observed (Table 1). Twelve (67\%) of the eighteen trimethoprim-resistant strains were also resistant to oxytetracycline (data not shown). No differences were observed in the distribution of MICs for oxytetracycline between $A$. hydrophila and A. caviae.

\section{Discussion}

There are approximately 20 catfish farms in The Netherlands together supplying $90 \%$ of the European market. Since we sampled all of the six farms in the southern part of The Netherlands, we believe that this should give a reliable reflection of the whole Dutch catfish industry, especially since the sampled catfish farms are similar with regard to size and culturing methods to the farms that have not been sampled. The fraction of eel farms sampled $(n=3)$ compared with the total number of eel farms in The Netherlands $(n \approx 40)$ is much smaller and therefore not a reliable reflection of the whole eel farm industry in The Netherlands.

In this study, the prevalence and degree of resistance in Dutch eel and catfish farms was determined using motile Aeromonas spp. as indicator bacteria. Aeromonas spp. are generally thought to be intrinsically susceptible to all antibiotics active against non-fastidious Gram-negative bacilli, except for many $\beta$-lactams owing to the production of multiple, inducible, chromosomally encoded $\beta$-lactamases.

All water samples tested showed a high degree of resistance to ampicillin. Of the strains isolated, $96 \%$ were resistant to ampicillin. This is in agreement with the intrinsic resistance to $\beta$-lactams and comparable with percentages of ampicillinresistant aeromonads found in other studies $[3,8]$. In contrast, a recent study showed that a significant proportion of environmental aeromonads (17\%) were susceptible to ampicillin [9].

Table 1

Antibiotic resistance $(\% R)$ and $\mathrm{MIC}_{50}$ and $\mathrm{MIC}_{90}$ values of Aeromonas spp. strains $(n=79)$ isolated from water samples of fish farms

\begin{tabular}{lcccr}
\hline Antibiotic & $\begin{array}{l}\text { Breakpoint } \\
(\mathrm{mg} / \mathrm{L})^{\mathrm{a}}\end{array}$ & \multicolumn{2}{l}{$\mathrm{MIC}(\mathrm{mg} / \mathrm{L})$} & $\% R$ \\
\cline { 3 - 4 } & & $\mathrm{MIC}_{50}$ & $\mathrm{MIC}_{90}$ & \\
\hline Ampicillin & 32 & $>256$ & $>256$ & 96 \\
Oxytetracycline & 16 & 16 & 128 & 65 \\
Trimethoprim & 4 & 1 & 8 & 23 \\
Ciprofloxacin & 4 & $<0.5$ & $<0.5$ & 0 \\
Chloramphenicol & 32 & $<4$ & $<4$ & 0 \\
\hline
\end{tabular}

MIC, minimal inhibitory concentration; $\mathrm{MIC}_{50 / 90}$, MIC for $50 \%$ and $90 \%$ of the organisms, respectively.

a Breakpoint concentrations modified according to National Committee for Clinical Laboratory Standards guidelines for non-fermenting Gramnegative rods. 
A high degree of oxytetracycline resistance was found in 23 of the 29 water samples tested, comprising all but one fish farm.

Of the isolated strains, $65 \%$ were resistant to oxytetracycline; no differences in susceptibility were found between $A$. caviae and A. hydrophila strains.

In a number of studies on the susceptibility of clinical isolates, the percentage of oxytetracycline-resistant Aeromonas strains was only $20 \%$ or less [10-12]. Studies on the susceptibility of motile Aeromonas strains isolated from European rivers and Turkish drinking water also reported a significantly lower percentage of oxytetracycline-resistant strains (14\% and $12 \%$, respectively) $[8,13]$. However, previous studies on antibiotic resistance in aquaculture found percentages of oxytetracycline-resistant Aeromonas strains similar to our results: rainbow trout in Denmark (oxytetracycline resistance 69\%) [14]; catfish in the USA (tetracycline resistance 46\%) [4]; and catfish in the USA (oxytetracycline resistance $62 \%$; tetracycline resistance $43 \%$ ) [3]. In a Japanese study in water samples derived from different Ayu farms, a prevalence of tetracycline resistance among Gram-negative rods of $100 \%$ was found, whereas no highdegree resistance was observed [5]. Thus, the percentage of oxytetracycline-resistant Aeromonas spp. strains in our study was comparable with the results of other studies on antibiotic resistance in aquaculture, however clinical and environmental isolates were less frequently resistant to oxytetracycline.

In several studies, the antibiotic susceptibility of clinical and river isolates of Aeromonas spp. for sulfamethoxazole/trimethoprim ranged between $75 \%$ and $93 \%$ $[8,10,11,13]$. Our findings were of the same order of magnitude, i.e. $77 \%$ of the strains were susceptible to trimethoprim and $76 \%$ to sulfamethoxazole.

In the present study, Aeromonas spp. was susceptible to chloramphenicol as well as ciprofloxacin, which is in agreement with the results of previous studies on antibiotic resistance in aquaculture as well as with the results of studies on clinical isolates $[3,4,10,11]$. However, in the Japanese Ayu farms chloramphenicol-resistant Gram-negative rods were frequently found, which might be due to the widespread use of chloramphenicol in those farms [5].

The predominant phenotypic resistance pattern of aeromonads isolated at Danish rainbow trout farms was combined oxytetracycline and sulfadiazine/trimethoprim resistance. In our study only $24 \%$ of the oxytetracyclineresistant strains were also resistant to trimethoprim.

Oxytetracycline is the only antibiotic for which a high degree of resistance was found in our study.

The degree of resistance to the antibiotics under study was generally comparable between the ten fish farms, although a high degree of oxytetracycline resistance was not found in one fish farm (number 9) and (low-degree) resistance to sulfamethoxazole was found in only one-half of the fish farms. These differences between farms could possibly reflect the administration of antibiotics.
Regardless of whether antibiotics were used or not, the fish farms under study are major reservoirs of oxytetracycline resistance genes. There are three potential ways in which antibiotic use in food animals may have consequences on human health. First, consumers can be exposed to antibiotic residues in eel or catfish. Due to the antibiotic withdrawal periods before harvesting the fish, this seems very unlikely. Second, there is the possibility that consumers come into contact with antibiotic-resistant pathogens present in the fish products. The bacterial microflora of fish and fish farms is usually not pathogenic for humans. Even when consumers are infected by microorganisms from fish, this mostly results in a self-limiting gastroenteritis in which antibiotic treatment is not necessary [15]. However, A. hydrophila and Plesiomonas shigelloides, which are frequently present in the bacterial microflora of fish, can also cause sepsis in patients with impaired immune systems [15]. At immediate risk of such an infection are the fish farmers and processors, especially those whose immune system is compromised [3]. Several antibiotics, such as third-generation cephalosporins and fluoroquinolones, are recommended for treatment of $A$. hydrophila sepsis. However, recommended alternative therapies usually include trimethoprim/sulfamethoxazole and tetracycline [13]. Finally there is the potential transfer of antibiotic resistance genes from the bacterial microflora of fish to pathogenic bacteria in the intestines of consumers.

In vitro oxytetracycline-resistant Aeromonas spp. were demonstrated to transfer their resistance to E. coli [16]. In a study on the distribution of oxytetracycline-resistant plasmids between Aeromonas in hospital and aquaculture environments, Rhodes et al. [17] showed that spread of tetracycline resistance-coding plasmids did occur between Aeromonas spp. and E. coli as well as between human and aquaculture environments. However, the degree to which transfer of resistance from bacteria in meat or fish products to bacteria in the intestinal microflora of the consumers occurs remains largely unknown.

Notwithstanding the degree of transfer of resistance, according to our findings this will be limited to potential transfer of (oxy)tetracycline resistance. We found no resistance to ciprofloxacin and chloramphenicol, and resistance to sulfamethoxazole and trimethoprim was also limited to low-degree resistance of some of the samples.

However, since tetracyclines, especially doxycycline, are amongst the drugs of choice for the treatment of respiratory tract infections in general practice patients, this major reservoir of oxytetracycline resistance genes might form a risk to human health. However, a better understanding is crucial to assess this risk. In addition, tetracyclines are still used in large quantities prophylactically as well as therapeutically in food animals; therefore, loss of effectiveness of oxytetracycline to treat infections in aquaculture might also become a serious problem.

Funding: No funding sources.

Competing interests: None declared.

Ethical approval: Not required. 


\section{References}

[1] Frappaola PJ, Guest GB. Regulatory status of tetracyclines, penicillin and other antibacterial drugs in animal feeds. J Anim Sci 1986;62(Suppl. 3):86-92.

[2] Sørum H, Sunde M. Resistance to antibiotics in the normal flora of animals. Vet Res 2001;32:227-41.

[3] McPhearson RM, DePaola A, Zywno A, Motes ML, Guarino AM. Antibiotic resistance in Gram-negative bacteria from cultured catfish and aquaculture ponds. Aquaculture 1991;99:203-11.

[4] DePaola A, Peeler JT, Rodrick GE. Effect of oxytetracycline-medicated feed on antibiotic resistance of gram-negative bacteria in catfish ponds. Appl Environ Microbiol 1995;61:2335-40.

[5] Aoki T. Effects of chemotherapeutics on bacterial ecology in the water of ponds and the intestinal tracts of cultured fish, ayu (Plecoglossus altivelis). Jpn J Microbiol 1975;19:7-12.

[6] Akinbowale OL, Peng H, Grant P, Barton MD. Antibiotic and heavy metal resistance in motile aeromonads and pseudomonads from rainbow trout (Oncorhynchus mykiss) farms in Australia. Int J Antimicrob Agents 2007;30:177-82.

[7] Carnahan AM, Behram S, Joseph SW. Aerokey II: a flexible key for identifying clinical Aeromonas species. J Clin Microbiol 1991;29:2843-9.

[8] Goni-Urriza M, Pineau L, Capdepuy M, Roques C, Caumette P, Quentin C. Antimicrobial resistance of mesophilic Aeromonas spp. isolated from two European rivers. J Antimicrob Chemother 2000;46:297301.

[9] Huddleston JR, Zak JC, Jeter RM. Sampling bias created by ampicillin in isolation media for Aeromonas. Can J Microbiol 2007;53:39-44.
[10] Burgos A, Quindos G, Martinez R, Rojo P, Cisterna R. In vitro susceptibility of Aeromonas caviae, Aeromonas hydrophila and Aeromonas sobria to fifteen antibacterial agents. Eur J Clin Microbiol Infect Dis 1990;9:413-7.

[11] Chang BJ, Bolton SM. Plasmids and resistance to antimicrobial agents in Aeromonas sobria and Aeromonas hydrophila clinical isolates. Antimicrob Agents Chemother 1987;31:1281-2.

[12] Higgins CS, Murtough SM, Williamson E, Hiom SJ, Payne DJ, Russell $\mathrm{AD}$, et al. Resistance to antibiotics and biocides among non-fermenting Gram-negative bacteria. Clin Microbiol Infect 2001;7:308-15.

[13] Koksal F, Oguzkurt N, Samasti M, Altas K. Prevalence and antimicrobial resistance patterns of Aeromonas strains isolated from drinking water samples in Istanbul, Turkey. Chemotherapy 2007;53:30-5.

[14] Schmidt AS, Bruun MS, Dalsgaard I, Pedersen K, Larsen JL. Occurrence of antimicrobial resistance in fish-pathogenic and environmental bacteria associated with four Danish rainbow trout farms. Appl Environ Microbiol 2000;66:4908-15.

[15] Holmberg SD, Farmer 3rd JJ. Aeromonas hydrophila and Plesiomonas shigelloides as causes of intestinal infections. Rev Infect Dis 1984;6:633-9.

[16] Schmidt AS, Bruun MS, Dalsgaard I, Larsen JL. Incidence, distribution, and spread of tetracycline resistance determinants and integronassociated antibiotic resistance genes among motile aeromonads from a fish farming environment. Appl Environ Microbiol 2001;67:5675-82.

[17] Rhodes G, Huys G, Swings J, Mcgann P, Hiney M, Smith P, et al. Distribution of oxytetracycline resistance plasmids between aeromonads in hospital and aquaculture environments: implication of $\mathrm{Tn} 1721$ in dissemination of the tetracycline resistance determinant tetA. Appl Environ Microbiol 2000;66:3883-90. 